\title{
Gambaran Faktor Risiko Malnutrisi pada Anak Balita di Wilayah Kecamatan Tamalanrea Kota Makassar Tahun 2019
}

\author{
Hidro Muh Perdana ${ }^{1 *}$, Darmawansyih ${ }^{2}$, Andi Faradillah ${ }^{3}$ \\ ${ }^{1}$ Departemen Program Studi Sarjana Kedokteran, Fakultas Kedokteran dan Ilmu Kesehatan, UIN Alauddin \\ Makassar \\ ${ }^{2}$ Departemen Biomedik, Fakultas Kedokteran dan Ilmu Kesehatan, UIN Alauddin Makassar \\ ${ }^{3}$ Departemen Ilmu Gizi, Fakultas Kedokteran dan Ilmu Kesehatan, UIN Alauddin Makassar \\ *Email Korespondensi: perdanahidro09@gmail.com¹ Telp: 082197497370
}

\begin{abstract}
ABSTRAK
Latar belakang: Berdasarkan Riskesdas tahun 2018, angka kejadian gizi kurang pada balita sebesar 17,7\%. Wilayah Sulawesi Selatan merupakan salah satu wilayah dengan peringkat 10 tertinggi untuk prevalensi gizi kurang/malnutrisi dan gizi buruk pada balita yaitu $25,6 \%$, dan 6,6\%. Penelitian ini bertujuan untuk mengetahui gambaran faktor risiko gizi kurang pada anak balita di Wilayah Kecamatan Tamalanrea.

Metode: Jumlah sampel pada penelitian ini 77 anak balita dengan gizi kurang. Adapun pengambilan data pada penelitian ini berdasarkan angka kejadian malnutrisi pada anak balita di beberapa Puskesmas Kecamatan Tamalanrea, data rekam medis dan melakukan interview langsung dengan menggunakan kuisioner. Faktor risiko yang diteliti adalah riwayat pemberian ASI eksklusif, riwayat penyakit infeksi, riwayat berat badan lahir, tingkat pendidikan dan pengetahuan orang tua, dan status sosial ekonomi.

Hasil: Dari 77 sampel pasien dengan gizi kurang, terdapat 59 (76,6\%) anak balita yang tidak diberikan ASI eksklusif dengan gizi kurang, 39 (50,6\%) anak balita yang memilki riwayat penyakit infeksi dengan gizi kurang, $42(54,5 \%)$ anak balita yang memiliki riwayat berat badan lahir rendah dengan gizi kurang, $59(76,6 \%)$ orang tua dari pasien dengan tingkat pendidikan dan pengetahuan yang kurang dengan gizi kurang, 48 (62,3\%) keluarga dengan status sosial ekonomi yang rendah dengan gizi kurang.

Kesimpulan: Anak yang tidak mendapatkan ASI eksklusif, memiliki riwayat penyakit infeksi, memiliki riwayat berat lahir rendah, memiliki orang tua dengan tingkat pendidikan dan pengetahuan yang rendah, dan status sosial ekonomi yang rendah lebih banyak mengalami malnutrisi.
\end{abstract}

Kata Kunci: Gizi; anak balita; malnutrisi

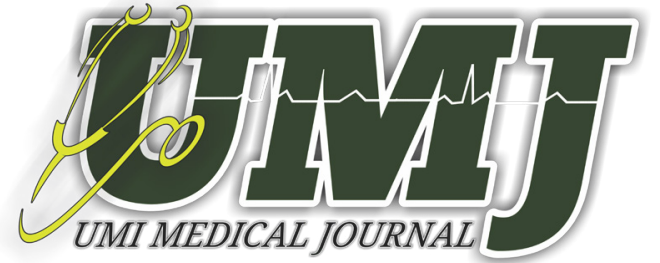

Article history:

Received: 1 May 2020

Accepted: 23 June 2020

Publish Online: 30 June 2020

Published By :

Fakultas Kedokteran

Universitas Muslim Indonesia

Phone:

+6282293330302
Address:

Jl. Urip Sumoharjo Km. 5 (Kampus II UMI)

Makassar, Sulawesi Selatan.

Email:

medicaljournal@umi.ac.id 


\begin{abstract}
Background: Based on Riskesdas in 2018, the incidence of malnutrition in infants was $17.7 \%$. South Sulawesi Region is one of the 10 regions with the highest prevalence of malnutrition / malnutrition) and malnutrition in children under five, namely $25.6 \%$ and $6.6 \%$. This study discusses nutritional risk factors for children under five in the Tamalanrea Region.

Method: The number of samples in this study were 77 children under five with malnutrition. When taking the data in this study on the incidence of malnutrition in children under five in several District Health Centers Tamalanrea, medical record data and conduct direct interviews using questionnaires. Facts about the published publications are exclusive breastfeeding, publications about infections, publications about birth weight, parents' level of education and knowledge, and socioeconomic status.

Results: From 77 samples of patients with malnutrition, there were 59 (76.6\%) children under five who were not exclusively breastfed with malnutrition, 39 (50.6\%) children under five who had a history of infectious disease with malnutrition, 42 (54), 5\%) children under five who have low birth weight with malnutrition, 59 (76.6\%) parents of patients with malnutrition level of education and knowledge, 48 (62.3\%) families with lower socioeconomic status low with poor nutrition.

Conclusions: Children who are not exclusively breastfed, have a history of infectious diseases, have a history of low birth weight, have parents with a low level of education and knowledge, and a lower socioeconomic status regarding malnutrition.
\end{abstract}

Keywords: Nutrition; children; malnutrition

\title{
PENDAHULUAN
}

Malnutrisi adalah asupan makanan kurang dari yang dibutuhkan pada seseorang yang berakibat terjadinya gangguan biologi dari orang tersebut. Secara umum malnutrisi terbagi atas dua bagian yaitu gizi kurang dan gizi lebih. Gizi kurang terdiri dari marasmus, kwashiorkor, serta marasmus-kwashiorkor, sedangkan gizi lebih disebut dengan obesitas. Malnutrisi yang terjadi pada tahap awal kehidupan dapat meningkatkan risiko infeksi, morbiditas, dan mortalitas bersamaan dengan penurunan perkembangan mental dan kognitif. (1) Menurut data dari WHO angka kejadian kekurangan gizi pada anak balita tahun 2014 sebanyak 50 juta anak dan gizi buruk sebanyak 16 juta anak.(2)

Berdasarkan Riskesdas tahun 2018, angka kejadian malnutrisi pada balita sebesar 17,7\%. Wilayah Sulawesi Selatan merupakan salah satu wilayah dengan peringkat 10 tertinggi untuk prevalensi gizi kurang dan gizi buruk pada balita yaitu 25,6\%, dan 6,6\%.(3) Hasil pemetaan yang dilakukan oleh Dinas Kesehatan Provinsi Sulawesi Selatan untuk prevalensi marasmus-kwashiorkor tertinggi adalah di Kota Makassar, dengan distribusi 16,39\% gizi kurang, dan 3,66\% gizi buruk.(4) 
Malnutrisi yang terjadi pada tahap awal kehidupan dapat meningkatkan risiko infeksi, morbiditas, dan mortalitas bersamaan dengan penurunan perkembangan mental dan kognitif.(5) Malnutrisi pada balita, membawa dampak negatif terhadap perkembangan motorik, menghambat perkembangan perilaku dan kognitif yang berakibat pada menurunnya prestasi belajar dan keterampilan sosial. Selain itu, kekurangan gizi selama masa kanak-kanak menyebabkan konsekuensi jangka panjang yang serius di kemudian hari yang meningkatkan risiko terserang penyakit atau cacat dan bahkan kematian.(6) Berdasarkan latar belakang yang dikemukakan tersebut, peneliti ingin mengetahui lebih lanjut tentang gambaran faktor risiko malnutrisi pada anak balita di wilayah Kecamatan Tamalanrea, Kota Makassar tahun 2019.

\section{METODE}

Penelitian ini dilakukan di beberapa Puskesmas Wilayah Kecamtan Tamalanrea pada tanggal 23 Desember 2019 sampai dengan 23 Januari 2020. Penelitian ini bertujuan untuk mengetahui gambaran faktor risiko gizi kurang pada anak balita di Wilayah Kecamatan Tamalanrea. Populasi dalam penelitian ini adalah seluruh anak balita yang mengalami gizi kurang di beberapa wilayah Kecamatan Tamalnrea. Adapun pengambilan data pada penelitian ini berdasarkan angka kejadian malnutrisi pada anak balita di beberapa Puskesmas Kecamatan Tamalanrea, data rekam medis dan melakukan interview langsung dengan menggunakan kuisioner. Jumlah sampel pada penelitian ini 77 anak balita dengan gizi kurang yang telah memenuhi kriteria inklusi. Kriteria inklusi dalam penelitian adalah balita yang bersedia ikut dalam penelitian, balita yang mengalami malnutrisi, dan memiliki data rekam medik yang lengkap dan dapat dievaluasi. Adapun kriteria eksklusi dalam penelitian ini adalah anak balita yang mengalami gangguan jiwa, anak balita yang mengalami kelainan kongenital, dan balita yang pindah dari tempat domisili saat penelitian berlangsung. Instrumen yang digunakan pada penelitian ini adalah kuisioner.

\section{HASIL}

Tabel 1. Distribusi Frekuensi Pemberian ASI Eksklusif

\begin{tabular}{ccc}
\hline \multirow{2}{*}{ Pemberian ASI Eksklusif } & \multicolumn{3}{c}{ Status Gizi } \\
\cline { 2 - 3 } & \multicolumn{3}{c}{ Malnutrisi } \\
\cline { 2 - 3 } & $\mathbf{n}$ & $\mathbf{\%}$ \\
\hline Tidak & 59 & 76.6 \\
\hline Ya & 18 & 23.4 \\
\hline Total & 77 & 100 \\
\hline
\end{tabular}

Berdasarkan Tabel 1, diketahui dari 77 total sampel pasien dengan gizi kurang, terdapat 59 (76,6\%) anak balita yang tidak diberikan ASI eksklusif dengan gizi kurang. Dengan demikian, dapat disimpulkan bahwa lebih banyak anak yang tidak diberikan ASI eksklusif menderita gizi kurang. 
Tabel 2. Distribusi Frekuensi Riwayat Penyakit Infeksi

\begin{tabular}{ccc}
\hline & \multicolumn{2}{c}{ Status Gizi } \\
\cline { 2 - 3 } Riwayat Penyakit Infeksi & \multicolumn{2}{c}{ Malnutrisi } \\
\cline { 2 - 3 } & $\mathbf{n}$ & $\mathbf{\%}$ \\
\hline Ya & 39 & 50.6 \\
\hline Tidak & 38 & 49.4 \\
\hline Total & 77 & 100 \\
\hline
\end{tabular}

Berdasarkan Tabel 2, diketahui dari 77 total sampel pasien dengan gizi kurang, terdapat 39 (50,6\%) anak balita yang memilki riwayat penyakit infeksi dengan gizi kurang. Dengan demikian, dapat disimpulkan bahwa lebih banyak anak yang memiliki riwayat penyakit infeksi menderita gizi kurang

\section{Tabel 3. Distribusi Frekuensi Riwayat Berat Badan Lahir}

\begin{tabular}{ccc}
\hline \multirow{2}{*}{$\begin{array}{c}\text { Riwayat Berat Badan } \\
\text { Lahir }\end{array}$} & \multicolumn{2}{c}{ Status Gizi } \\
\cline { 2 - 3 } & \multicolumn{2}{c}{ Malnutrisi } \\
\cline { 2 - 3 } & $\mathbf{n}$ & $\mathbf{\%}$ \\
\hline Rendah & 42 & 54.5 \\
\hline Normal & 35 & 45.5 \\
\hline Total & 77 & 100 \\
\hline
\end{tabular}

Berdasarkan Tabel 3, diketahui dari 77 total sampel pasien dengan gizi kurang, terdapat 42 (54,5\%) anak balita yang memiliki riwayat berat badan lahir rendah dengan gizi kurang. Dengan demikian, dapat disimpulkan bahwa lebih banyak anak yang tmemiliki riwayat berat badan lahir menderita gizi kurang.

Tabel 4. Distribusi Frekuensi Tingkat Pendidikan dan Pengetahuan

\begin{tabular}{ccc}
\hline & \multicolumn{2}{c}{ Status Gizi } \\
Tingkat Pendidikan dan & \multicolumn{2}{c}{ Malnutrisi } \\
\cline { 2 - 3 } Pengetahuan Orang Tua & \multicolumn{2}{c}{ \% } \\
\cline { 2 - 3 } & $\mathbf{n}$ & 76.6 \\
\hline Kurang & 59 & 23.4 \\
\hline Baik & 18 & 100 \\
\hline Total & 77 &
\end{tabular}

Berdasarkan Tabel 4, diketahui dari 77 total sampel pasien dengan gizi kurang, terdapat 59 (76,6\%) orang tua dari pasien dengan tingkat pendidikan dan pengetahuan yang kurang dengan gizi kurang. Dengan demikian, dapat disimpulkan bahwa lebih banyak orang tua dari pasien dengan tingkat pendidikan dan pengetahuan yang kurang menderita gizi kurang 
Tabel 5. Distribusi Frekuensi Sosial Ekonomi

\begin{tabular}{ccc}
\hline \multirow{2}{*}{ Sosial Ekonomi } & \multicolumn{2}{c}{ Status Gizi } \\
\cline { 2 - 3 } & \multicolumn{2}{c}{ Malnutrisi } \\
\cline { 2 - 3 } & $\mathbf{n}$ & $\mathbf{\%}$ \\
\hline Rendah & 48 & 62.3 \\
\hline Baik & 29 & 37.7 \\
\hline Total & 77 & 100 \\
\hline
\end{tabular}

Berdasarkan Tabel 5, diketahui dari 77 total sampel pasien dengan gizi kurang, terdapat 48 (62,3\%) keluarga dengan status sosial ekonomi yang rendah dengan gizi kurang. Dengan demikian, dapat disimpulkan bahwa lebih banyak keluarga dengan status sosial ekonomi yang rendah menderita gizi kurang.

\section{PEMBAHASAN}

Pemberian ASI eksklsuif sangat dianjurkan diberikan karena ASI sangat bermanfaat pada proses pertumbuhan dan perkembangan anak. ASI mengandung karbohidrat, protein, dan lemak berfungsi sebagai sumber energi baik untuk tubuh maupun otak. Selain itu, protein pada

ASI sangat mudah dicerna oleh usus sehingga dapat mencegah kemungkinan bayi terkena penyakit gangguan gastrointestinal. Sesuai dengan hasil penelitian ini dimana banyak anak yang menderita malnutrisi yang tidak mendapatkan ASI eksklusif. Hal ini sejalan dengan penelitian yang dilakukan Sihombing Natalia (2017) dimana lebih banyak yang menderita malnutrisi yang tidak mendapatkan ASI eksklusif. Kolostrum merupakan cairan berwarna kekunigan dan keluar dari payudara ibu pada beberapa jam pertama, banyak mengandung antibodi immunoglobulin A (IgA) yang berfungsi melapisi saluran cerna agar kuman tidak dapat masuk ke dalam aliran darah dan akan melindungi bayi sampai sistem imunitasnya berfungsi dengan baik. Selain manfaat diatas, ASI juga bermanfaat untuk tumbuh kembang anak, dan berfungsi sebagai imunitas untuk bayi.(7)

Selain faktor pemberian ASI eksklusif, riwayat penyakit infeksi juga menjadi salah satu faktor risiko terjadinya malnutrisi. Hal ini disebabkan gangguan penyerapan makanan dan jika kondisi ini terus menerus terjadi dalam jangka waktu lama maka akan mengakibatkan malabsorbsi gizi, dan perubahan metabolisme tubuh yang akhirnya berdampak pada status gizi balita. Hal ini sesuai dengan hasil penelitian ini dimana lebih banyak anak dengan riwayat penyakit infeksi yang menderita malnutrisi dibandingkan yang tidak memiliki riwayat penyakit infeksi. Hal ini sejalan dengan penelitian yang dilakukan Agung Dirgantara (2017) dimana lebih banyak anak yang memiliki riwayat penyakit infeksi mengalami malnutrisi. Oleh karena itu, semakin rendah kesadaran seorang ibu akan pentingnya menjaga kebersihan maka akan semakin rentan dengan paparan mikroorganisme ataupun agen infeksius lainnya. Dengan demikian, dibutuhkan kesadaran tinggi bagi seorang ibu untuk menjaga kebersihan agar dapat mengurangi ataupun mencegah terjadinya penyakit infeksi.(8) 
Penelitian ini juga menggambarkan tentang faktor risiko riwayat berat badan lahir terhadap kejadian malnutrisi. Asupan nutrisi selama masa kehamilan sangat penting agar kebutuhan zat gizi untuk ibu dan janin dapat terpenuhi secara maksimal. Hal ini sesuai dengan hasil penelitian yang saya dapatkan dimana banyak anak dengan riwayat berat badan lahir rendah menderita malnutrisi dibandingkan yang memiliki berat badan lahir normal. Hal ini sejalan yang dilakukan Priyo Sulistyo Bayi (2006) lebih banyak anak dengan berat badan lahir rendah mengalami malnutrisi. Berat badan lahir rendah dapat mengakibatkan pertumbuhan dan perkembangan lebih lambat, karena mengalami intra uterine growth restriction atau pertumbuhan janin terhambat sehingga efek jangka panjang yang dapat terjadi pertumbuhan dan perkembangan yang lebih. Adapun, berat bayi lahir normal dengan asupan gizi kurang serta masih rentan terinfeksi akibat paparan mikroorganisme maupun yang lainnya di awal kehidupan maka dapat mengakibatkan penurunan status gizi.(9)

Tingkat pendidikan dan pengetahuan orang tua juga dapat berpengaruh terhadap kejadian malnutrisi. Orang tua dengan pendidikan yang rendah akan lebih sulit menerima informasi baru dan mengubah tradisi atau kebiasaan makan. Semakin tinggi tingkat pendidikan seseorang, semakin mudah dia menyerap informasi yang diterima termasuk informasi gizi baik dan sehat.(10) Tingkat pendidikan sangat berpengaruh terhadap pola asuh, pola pemberian makanan untuk anak dan keluarganya. Orang tua dengan pendidikan baik cenderung lebih perhatian terhadap kesehatan anaknya. Selain itu, tingkat pendidikan orang tua erat kaitannya dengan social ekonomi keluarga tersebut.(11) Hal ini sejalan dengan hasil penelitian yang saya dapatkan dimana lebih banyak balita dengan orang tua yang memiliki tingkat pendidikan dan pengetahuan rendah mengalami malnutrisi dibandingkan dengan orang tua yang memiliki tingkat pendidikan dan pengetahuan yang baik. Hal ini sejalan dengan penelitian yang dilakukan Sihombing Natalia (2017) lebih banyak balita dengan orang tua yang memiliki tingkat pendidikan dan pengetahuan rendah mengalami malnutrisi. Orang tua dengan pendidikan yang rendah akan lebih sulit menerima informasi baru dan mengubah tradisi atau kebiasaan makan. Semakin tinggi tingkat pendidikan seseorang, semakin mudah dia menyerap informasi yang diterima termasuk informasi gizi baik dan sehat.(10)

Status sosial ekonomi merupakan faktor yang paling menentukan terhadap jenis dan makanan yang dikonsumsi. Apabila suatu keluarga memiliki status sosial ekonomi yang rendah, maka akan mengakibatkan terbatasnya membeli bahan-bahan pangan, sehingga menyebabkan konsumsi makanan akan berkurang yang dapat mengakibatkan perubahan berat badan anak dan pada akhirnya dapat mengalami gizi kurang. Sebaliknya jika suatu keluarga memiliki tingkat pendapatan yang baik sehingga mereka mampu membeli bahan-bahan pangan, dan zat-zat gizi dapat terpenuhi secara maksimal. Hal ini sesuai dengan penelitian yang saya dapatkan dimana lebih banyak balita dengan keluarga status sosial ekonomi rendah mengalami malnutrisi dibandingkan keluarga dengan status sosial ekonomi baik. Hal ini sejalan dilakukan Sihombing Natalia (2017) lebih banyak balita dengan keluarga status sosial ekonomi rendah mengalami malnutrisi. 


\section{KESIMPULAN}

Pada penelitian ini didapatkan bahwa anak yang tidak mendapatkan ASI eksklusif, memiliki riwayat penyakit infeksi, memiliki riwayat berat lahir rendah, memiliki orang tua dengan tingkat pendidikan dan pengetahuan yang rendah, dan status sosial ekomi yang rendah lebih banyak mengalami malnutrisi.

\section{DAFTAR PUSTAKA}

1. Ari Syam Fahrial. Malnutrisi. Buku Ilmu Penyakit Dalam. Jilid I Edisi VI: Interna Publishing; 2014.

2. Riset Kesehatan Nasional. Angka Kejadian Malnutrisi di Indonesia. Kementerian Kesehatan Republik Indonesia; 2018.

3. Departemen Kesehatan Republik Indonesia. Laporan kasus angka kejadian gizi kurang dan gizi buruk pada anak balita di Indonesia; 2014.

4. Dinas Kesehatan Provinsi Sulawesi Selatan. Laporan kasus angka kejadian gizi kurang dan gizi buruk pada anak balita di Kota Makassar; 2014.

5. Soetjiningsih, IGN Gde Ranuh. Tumbuh Kembang Anak. Edisi 2. Jakarta: Penerbit Buku Kedokteran EGC; 2013.

6. Karen JM, Robert K, Hal J, Richard B. Nelson Ilmu Kesehatan Anak Esensial 6th Edition. Elsevier; 2014. p.896.

7. Ikatan Dokter Anak Indonesia. Nilai Nutrisi Air Susu Ibu; 2013.

8. Sihombing N. Analisis Faktor-Faktor yang Mempengaruhi Kejadian Gizi Kurang pada Anak Balita di wilayah kerja Puskesmas Saitnihuta Kecamatan Doloksanggul, Kabupaten Humbang Hasundutan. Sumatera: Fakultas Kesehatan Masyarakat Universitas Sumatera Utara; 2017.

9. Prawirahardjo Sarwono. Ilmu Kebidanan: Patologi dan fisiologi persalinan. Jakarta: PT. Bina Pustaka Sarwono Prawirahardjo; 2014.

10. Ernawati, A. Hubungan faktor sosial ekonomi, higiene sanitasi lingkungan, tingkat konsumsi,dan infeksi dengan status gizi anak usia 2-5 tahun di Kabupaten Semarang. Semarang: Universitas Diponegoro; 2006 .

11. Amsalu S. Risk factors for severe acute malnutrition in children under the age of five: a case control study. Ethiopian Journal of Health Development. 2008;22(1):121-5. 